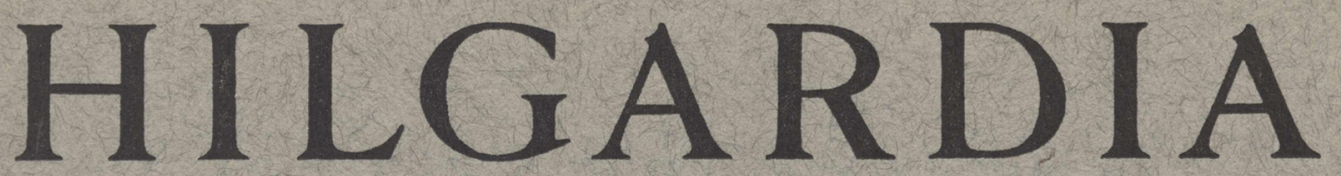

A Journal of Agricultural Science Published by the California Agricultural Experiment Station

\title{
RECLAMATION OF \\ A SALINE AND HIGH BORON SOIL IN THE COACHELLA VALLY OF CALIFORNIA
}

R. C. REEVE, A. F. PILLSBURY, and L. V. WILCOX 
With the expansion of irrigated agriculture throughout the world, much land now saline or alkaline must be reclaimed. Reported herein are the results of both flushing and leaching salts from a saline-alkali soil in the Coachella Valley of California's Colorado Desert. The paper presents a quantitative evaluation of the effectiveness of removing a salt crust by flushing, and it compares the removal of the usual salts with the removal of a high concentration of boron.

Flushing as a reclamation procedure was found to be ineffective. Leaching was found to remove 80 per cent of the initially high salts with the application of one foot of water for each foot depth of soil considered. Equal leaching of boron required three times as much water. 


\title{
$\begin{array}{lllllllll}H & I & L & G & A & R & D & \text { I } & A\end{array}$
}

A Journal of Agricultural Science Published by

the California Agricultural Experiment Station

VoL. 24

SEPTEMBER, 1955

No. 4

\section{RECLAMATION OF A SALINE AND HIGH BORON SOIL IN THE COACHELLA VALLEY OF CALIFORNIA ${ }^{1}$}

\author{
R. C. Reeve, A. F. PIllsbury, and L. V. WILCOX ${ }^{2}$
}

\section{INTRODUCTION}

Reclamation experiments have been conducted in the Coachella Valley of California, in which the rate of removal and general requirements for the leaching of boron from a soil have been quantitatively compared with those for the leaching of the usual salts found in saline-alkali soils. Also evaluated was the effectiveness of flushing the top crust of salts from the surface of the soil in relation to leaching.

These studies were undertaken in response to problems arising from recently accelerated irrigation development in the Coachella Valley, in which a relatively large fraction of the agricultural land to be developed-about one third-is adversely affected with salinity. Early development, restricted by the availability of ground water, permitted selection of the better soils scattered throughout the Valley. The importation of Colorado River water under the Boulder Canyon Project in 1948, and the construction of a distribution system to provide water for a total of approximately 80,000 acres gave need for information on procedures for reclaiming lands adversely affected with salinity. Since 1948, the irrigated acreage has increased from 20,000 to about 50,000 and has included much land previously saline.

Investigations by Huberty, et al. $(1948)^{3}$ showed that saline soils within the Valley were reclaimable by leaching with Colorado River water. They demonstrated that salts could be leached from the soil by ponding and passing water through the soil profile. They further suggested the possibility of removing highly concentrated surface salt crusts by flushing water over the surface. This procedure would eliminate the necessity of leaching high salt concentrations through relatively impervious soil profiles. Various modifications of the flushing process have been tried in this and in other countries

\footnotetext{
${ }^{1}$ Received for publication August 25, 1954.

${ }^{2}$ Agricultural Engineer, United States Salinity Laboratory, Riverside, California; Professor of Irrigation, University of California at Los Angeles; and Soil Scientist, United States Salinity Laboratory, Riverside, California, respectively.

${ }^{3}$ See "Literature Cited" for citations, referred to in the text by author and date.
} 
but quantitative data on the effectiveness of flushing to remove salt have been lacking.

The amelioration of saline and alkali soils is an old problem which has received considerable study (Hilgard, 1907; Harris, 1920 ; Catlin and Vinson, 1925 ; Kelley and Thomas, 1928; Burgess, 1928 ; Wursten and Powers, 1934 ; Thomas, 1936 ; Snyder, et al., 1940; Fitts, et al., 1943; Gardner, 1945 ; Reeve, et al., 1948; Kelley, 1951; Bower, et al., 1951). As a result of these and of other studies, many of the underlying principles involved in the improvement of saline and alkali soils are now known. Recent research findings and a summary of the principles involved in the diagnosis and improvement of saline and alkali soils are given in the United States Department of Agriculture Handbook No. 60 (1954).

Following the initiation of the flushing and leaching studies boron was found to be present in the soil at the experimental location in extremely toxic concentrations. The boron problem, therefore, quite by accident became a part of this reclamation study. The rate of removal of boron and its effect upon crop growth were among the more important aspects studied.

Boron has a marked effect upon crop growth, both from the standpoint of plant nutrition if it is deficient in the soil and of toxicity if it is present in excessive amounts. The presence of excessive amounts, with the resulting injury to crops (Kelley and Brown, 1928 ; Scofield and Wilcox, 1931 ; Eaton, 1935 ; Eaton and Wilcox, 1939; Eaton, et al., 1941) is often associated with the use of irrigation water that contains excessive amounts of boron.

Although boron is necessary in minute quantities for normal plant growth, it is toxic to plants even in relatively low concentrations. Eaton and Wilcox (1939) reported that boron concentrations as low as 0.5 to $5.0 \mathrm{ppm}$ in the saturation extract may cause injury to agricultural crops. It is further pointed out that plant species exhibit wide differences in both their boron requirements and their boron tolerances. With some plants, injury results when the concentrations of boron best suited to growth are only slightly exceeded, whereas with others there is a rather broad range over which plant growth is little affected. Research has shown that damage from boron results from its accumulation in the plant tissues.

The results of the several investigators of the boron toxicity problem that are listed above show that boron can be leached from the soil. The results further show that boron as found in soils does not leach as readily as do other soluble salts commonly found in saline soils.

The boron problem encountered in the present study is one in which boron was initially present in the soil. The source and the processes by which it accumulated in this soil are not known, but inasmuch as the experimental site was located on virgin soil, here the boron problem is independent of the irrigation water.

No attempt is made in this study to define the extent of the boron problem in the Coachella Valley. However, analyses of a limited number of samples from various locations within the Valley indicate that the problem is not general in nature, but that it may occur in localized areas. Kelley and Brown as early as 1928 reported that ". . boron toxicity . . occurs in certain grapefruit orchards near Oasis in the Coachella Valley." This is indicative of the "spotted" nature of the problem as it occurs in the Coachella Valley. 


\section{CHARACTERISTICS OF THE SOIL STUDIED}

An experimental site for the flushing and leaching experiments was selected in the NW cor. of the SW $1 / 4$ of the SE $1 / 4$ of Section 3, T6S, R8E, approximately 3 miles east of the city of Coachella. The soil at this location was classified by Kocher and Harper in 1928 as Indio clay loam, silty phase. Drainage was not a problem inasmuch as the water table was at a depth greater than 20 feet throughout the course of the experiment.

The soils of the Coachella Valley were developed under an arid climate with daily temperatures of $100^{\circ} \mathrm{F}$ or greater for extended periods throughout the year. The average annual precipitation is less than 3 inches and so un-

Table 1

PARTICLE SIZE DISTRIBUTION DATA FOR THE SOIL STUDIED

\begin{tabular}{|c|c|c|c|c|c|c|c|}
\hline \multirow{2}{*}{ Soil separate } & \multirow{2}{*}{$\begin{array}{c}\text { Particle } \\
\text { size }\end{array}$} & \multicolumn{6}{|c|}{ Sampling depth, in inches } \\
\hline & & $0-6$ & $6-12$ & $12-24$ & $24-32$ & $32-48$ & $48-60$ \\
\hline & $m m$ & per cent & per cent & per cent & per cent & per cent & per cent \\
\hline USDA classification & & & & & & & \\
\hline Fine gravel........ & $2-1$ & 0.2 & 0.6 & 0.4 & 0.1 & 0.1 & 0.2 \\
\hline Coarse sand.... & $1-.5$ & 0.4 & 0.9 & 0.6 & 0.6 & 2.9 & 0.3 \\
\hline Medium sand. . & $.5-.25$ & 0.5 & 0.6 & 0.4 & 1.7 & 14.3 & 0.7 \\
\hline Fine sand... & $.25-.1$ & 4.6 & 4.6 & 3.3 & 19.9 & 49.1 & 10.8 \\
\hline Very fine sand.. & $.1-.05$ & 16.9 & 11.8 & 8.0 & 28.5 & 22.4 & 32.1 \\
\hline Silt............ & $.05-.002$ & 61.8 & 69.1 & 71.4 & 42.3 & 11.2 & 48.2 \\
\hline Clay ................ & $.002-0$ & 15.6 & 12.4 & 15.9 & 6.9 & 0.0 & 7.7 \\
\hline $\begin{array}{l}\text { ISSS classification } \\
\quad \text { III } \ldots \ldots \ldots \ldots \ldots \ldots\end{array}$ & $.02-.002$ & 35.4 & 39.9 & 44.3 & 17.9 & 2.0 & 17.1 \\
\hline
\end{tabular}

evenly distributed that frequently periods of many months elapse with no rain falling in measurable quantities. The soils of the Coachella Valley are deficient in organic matter; they are highly micaceous, light colored throughout the entire profile, and irregularly stratified, with no uniformity in thickness, texture, or order of strata arrangement. All have been derived from unconsolidated materials transported and redistributed by water or wind. The soil at the experimental site, Indio clay loam, silty phase, is a gray, calcareous, laminated soil very low in organic matter.

The soil profile at the experimental location showed four marked textural changes within a depth of 5 feet. Soil samples both disturbed and undisturbed were taken from a pit centrally located within the plot area, for characterization of the soil with respect to chemical and physical properties. The results of particle size analyses are shown in table $1 .^{4}$

These data show that the soil is fairly high in silt to a depth of 24 inches and that layers of very fine sandy loam and fine sand underlie the top soil at a depth of 24 to 32 and 32 to 48 inches, respectively.

The percentages of moisture retained at various soil moisture tensions

${ }^{4}$ Particle size analyses by United States Department of Agriculture, Soil Survey Laboratory, Riverside, California. 
by undisturbed soil in cores taken from three horizons in the profile are given in table 2. Each value reported is the average for triplicate cores. Average bulk density figures are also given for the three soil horizons.

The hydraulic conductivity of both fragmented and soil cores from various depths of the soil studied is presented in table 3 . These data both for the

Table 2

MOISTURE RETENTION AND BULK DENSITY

DETERMINATIONS ON SOIL CORES FROM THREE LAYERS OF THE SOIL STUDIED

\begin{tabular}{|c|c|c|c|c|c|}
\hline \multirow{2}{*}{ Depth } & \multirow{2}{*}{$\underset{\text { density }}{\text { Bulk }}$} & \multicolumn{4}{|c|}{ Soil moisture tension-millibars } \\
\hline & & 30 & 100 & 345 & 1,033 \\
\hline inches & $\mathrm{gm} . / \mathrm{cm}^{3}$ & \multicolumn{4}{|c|}{ Per cent water-Dry weight basis* } \\
\hline $6-12$ & 1.035 & 48.7 & 46.6 & 39.0 & 31.4 \\
\hline $12-24$ & 1.175 & 41.2 & 38.9 & 34.5 & 29.9 \\
\hline $24-32$ & 1.433 & 29.0 & 26.7 & 23.8 & 16.7 \\
\hline
\end{tabular}

* Each value is the average of three replicates.

Table 3

HYDRAULIC CONDUCTIVITY VALUES FOR CORES

AND FRAGMENTED SAMPLES TAKEN AT

VARIOUS DEPTHS FROM THE

SOIL STUDIED

\begin{tabular}{|c|c|c|c|c|}
\hline \multirow{3}{*}{ Sampling depth } & \multicolumn{4}{|c|}{ Hydraulic conductivity } \\
\hline & \multicolumn{2}{|c|}{ Fragmented } & \multicolumn{2}{|c|}{ Cores* } \\
\hline & Initial & After $24 \mathrm{hrs}$ & Initial & After $24 \mathrm{hrs}$ \\
\hline inches & $\mathrm{cm} / \mathrm{hr}$ & $\mathrm{cm} / \mathrm{hr}$ & $\mathrm{cm} / \mathrm{hr}$ & $\mathrm{cm} / \mathrm{hr}$ \\
\hline $0-6 \ldots \ldots \ldots \ldots \ldots$ & 0.22 & 0.35 & $\ldots$ & $\ldots$ \\
\hline $6-12 \ldots \ldots \ldots \ldots \ldots$ & 0.56 & 0.66 & 0.93 & 1.07 \\
\hline $12-24 \ldots \ldots \ldots \ldots \ldots \ldots$ & 0.15 & 0.20 & 0.14 & 0.02 \\
\hline $24-32 \ldots \ldots \ldots \ldots \ldots$ & 0.25 & 0.28 & 0.38 & 0.15 \\
\hline $32-48 \ldots \ldots \ldots \ldots \ldots$ & 2.74 & 2.0 & $\ldots$ & $\ldots$ \\
\hline $48-60 \ldots \ldots \ldots \ldots \ldots$ & 0.41 & 0.28 & $\cdots$ & $\cdots$ \\
\hline
\end{tabular}

* Each value is the average of six cores.

fragmented soil and core determinations show that the hydraulic conductivity is lowest for the 12- to 24-inch layer of soil which is the layer of finest texture in the profile. However, the hydraulic conductivity of all layers is sufficiently high so that the rate of water movement in this soil is not particularly a problem.

The results of chemical determinations made to characterize the soil at this location are given in table 4 . These data show the soil to be calcareous, low in organic matter, and high in exchangeable sodium. The soil is highly 
saline, as indicated by the electrical conductivity of the saturation extract, and excessively high in boron. The soil is classed as saline-alkali; however, in the first 2 feet the quantity of gypsum present is in excess of that required to replace all of the exchangeable sodium.

Table 4

CHEMICAL CHARACTERISTICS OF THE SOIL STUDIED

\begin{tabular}{|c|c|c|c|c|c|c|c|c|}
\hline \multicolumn{9}{|c|}{ Soil determinations } \\
\hline Sampling depth & $\begin{array}{l}\text { Satura- } \\
\text { tion per- } \\
\text { centage }\end{array}$ & $\begin{array}{l}\mathrm{pH} \text { of } \\
\text { saturated } \\
\text { soil }\end{array}$ & $\begin{array}{l}\text { Gypsum } \\
\text { content }\end{array}$ & $\begin{array}{c}\text { Organic } \\
\text { matter } \\
\text { content }\end{array}$ & $\begin{array}{l}\text { Insoluble } \\
\text { carbonate }\end{array}$ & $\begin{array}{l}\text { Cation } \\
\text { exchange } \\
\text { capacity }\end{array}$ & $\begin{array}{l}\text { Exchange- } \\
\text { able } \\
\text { sodium }\end{array}$ & $\begin{array}{c}\text { Exchangeable } \\
\text { sodium } \\
\text { percentage }\end{array}$ \\
\hline inches & & & $\begin{array}{c}\text { meq per } \\
100 \mathrm{gm}\end{array}$ & per cent & & $\begin{array}{l}\text { meq per } \\
100 \mathrm{gm}\end{array}$ & $\begin{array}{l}\text { meq per } \\
100 \mathrm{gm}\end{array}$ & \\
\hline $0-6$ & 53 & 8.6 & 58 & 0.8 & med. & 16.2 & 8.2 & 51 \\
\hline $6-12$ & 55 & 8.5 & 36 & 0.6 & med. & 16.8 & 10.8 & 64 \\
\hline $12-24$ & 60 & 8.6 & 14 & 0.3 & med. & 19.4 & 11.8 & 61 \\
\hline $24-32$ & 43 & 8.7 & 1.6 & 0.2 & low & 9.6 & 6.4 & 67 \\
\hline $32-48$ & 34 & 8.7 & $\operatorname{tr}$. & $\operatorname{tr}$ & $\operatorname{tr}$ & 3.8 & 2.5 & 66 \\
\hline $48-60$ & 50 & 8.0 & tr. & 0.1 & low & 11.0 & 3.8 & 35 \\
\hline
\end{tabular}

Saturation extract determinations

\begin{tabular}{|c|c|c|c|c|c|c|c|c|c|}
\hline \multirow{2}{*}{ Sampling depth } & \multirow{2}{*}{$\begin{array}{c}\text { Elec- } \\
\text { trical con- } \\
\text { ductivity } \\
\text { at } 25^{\circ} \mathrm{C}\end{array}$} & \multicolumn{3}{|c|}{ Cations } & \multicolumn{4}{|c|}{ Anions } & \multirow{2}{*}{ Boron } \\
\hline & & $\mathrm{Na}$ & $\mathbf{K}$ & $\mathrm{Ca}+\mathrm{Mg}$ & $\mathrm{Cl}$ & $\mathrm{SO}_{4}$ & $\mathrm{HCO}_{3}$ & $\mathrm{CO}_{3}$ & \\
\hline inches & $m m h o s / \mathrm{cm}$ & \multicolumn{7}{|c|}{ Milliequivalents per liter } & ppm \\
\hline $0-6$ & 75 & 1,290 & 16.4 & 44.1 & 627 & 679 & 2.8 & 3.8 & 50 \\
\hline $6-12$ & 41 & 553 & 6.9 & 31.9 & 247 & 335 & 1.7 & 2.0 & 35 \\
\hline $12-24$ & 36 & 450 & 4.0 & 29.3 & 217 & 258 & 0.8 & 1.2 & 26 \\
\hline $24-32$ & 26 & 305 & 1.5 & 22.7 & 174 & 149 & 0.2 & 1.0 & 15 \\
\hline $32-48$ & 10 & 102 & 0.6 & 6.6 & 55 & 53 & 0.8 & 0.4 & 6 \\
\hline $48-60$ & 12 & 97 & 0.6 & 25.3 & 100 & 21 & 0.7 & 0 & 5 \\
\hline
\end{tabular}

The chemical composition of Colorado River water, which was used in this study, is shown in table 5. This water is moderately high in total salt but has a favorable sodium percentage.

\section{EXPERIMENTAL PROCEDURE}

The effectiveness of leaching salts and boron from the soil was determined by soil analyses and by response of oat crops grown on two occasions on small plots leached with various amounts of water. The effectiveness of flushing in the removal of salt was determined by the change in salt content of water flushed over the top of the soil surface.

Plot Preparation and Experimental Design. Inasmuch as flushing is a procedure to remove salts from the soil surface and leaching is a method of removing salts from the soil profile, the experiment was designed to permit both flushing and leaching to be evaluated at the same experimental location by conducting the flushing trials prior to the leaching tests. 
Figure 1 shows the flushing strip and leaching plot layout with a list of treatments applied and a graph showing the sequence of operations.

An area approximately 100 feet by 330 feet was graded to give a flat crossslope and a longitudinal slope of 0.2 per cent. Earth borders were constructed 20 feet apart and parallel to the long dimension of the area to form five flushing strips. After the flushing trials were completed, cross-borders were constructed at intervals along four of the flushing strips to give 16 independent, enclosed leaching plots, 20 by 30 feet on a side, in a Latin square arrangement with a 10 -foot space between plots.

Table 5

CHEMICAL COMPOSITION OF COLORADO RIVER WATER*

\begin{tabular}{|c|c|c|c|c|c|c|c|c|c|c|c|c|}
\hline \multirow{2}{*}{$\underset{\text { at } 25^{\circ}{ }^{106 \dagger}}{\mathrm{EC}} \times{ }^{10}$} & \multirow{2}{*}{$\begin{array}{c}\text { Dissolved } \\
\text { solids }\end{array}$} & \multirow{2}{*}{$\begin{array}{l}\text { Sum of } \\
\text { cations }\end{array}$} & \multirow{2}{*}{ Boron } & \multicolumn{3}{|c|}{ Cations } & \multicolumn{4}{|c|}{ Anions } & \multirow{2}{*}{$\begin{array}{l}\text { Soluble } \\
\text { sodium } \\
\text { per- } \\
\text { centage }\end{array}$} & \multirow{2}{*}{$\begin{array}{l}\text { Sodium } \\
\text { adsorp- } \\
\text { tion } \\
\text { ratio } \ddagger\end{array}$} \\
\hline & & & & $\mathrm{Ca}$ & $\mathrm{Mg}$ & $\mathrm{Na}$ & $\mathrm{CO}_{3}$ & $\mathrm{HCO}_{3}$ & $\mathrm{SO}_{4}$ & $\mathrm{Cl}$ & & \\
\hline & $p p m$ & $m e q / 1$ & ppm & \multicolumn{7}{|c|}{ Milliequivalents per liter } & & \\
\hline 1,010 & 700 & 10.37 & 0.15 & 3.54 & 2.43 & 4.30 & 0.12 & 1.88 & 5.92 & 2.40 & 41 & 2.0 \\
\hline
\end{tabular}

* Sampled 8/12/53 at Coachella, California, by Otis A. Harvey.

$\dagger$ Electrical conductivity.

$\ddagger$ Sodium Adsorption Ratio $(\mathrm{SAR})=\frac{\mathrm{Na}^{+}}{\left(\mathrm{CA}^{++}+\mathrm{Mg}^{++}\right) / 2}$

Treatments. For the flushing treatment, a relatively large flow of water was passed over the flushing strips. One strip was corrugated to simulate the condition in a field operation where special water-control measures might be required.

Leaching treatments were applied to the plots on three different occasions. At the outset of the experiment in 1951 four leaching treatments, replicated four times in the Latin square arrangement, were applied to the plots. After the soil was sampled and the first oat crop was grown for evaluating the first series of leaching treatments, two additional increments of water were applied to one half the total number of plots on two different occasions (second and third leachings, fig. 1). Following each leaching, soil samples were obtained, and after the third leaching the area was cropped a second time to evaluate the effect of the total leaching treatments. In this manner, comparisons were obtained for leaching treatments of $0,1,2,4,6,8,10$, and 12 feet of water with an oat crop being grown on all leaching levels except 6 and 8 feet of water.

Flushing Operation. The flushing operation consisted of passing approximately a 3 c.f.s. stream of Colorado River water over the soil surface of the strips, which were 20 feet wide, and wasting the effluent at the terminal end. Water was metered from an underground pipeline distribution system to each border. Inasmuch as the initial salt crust was mixed with the soil in the leveling process, the border strips were alternately wetted and allowed to dry several times prior to the flushing test to re-create a salt crust on the soil 
surface similar to the soil in the virgin condition. Each border strip was then surface-flushed, and the electrical conductivity and rate of discharge of the water from the lower end of the strip were measured. A Parshall flume was used for discharge measurements. The net amount of salt removed was calculated from electrical conductivity and water flow measurements on and off the strips.

Leaching Operation. Colorado River water was metered on to each plot by means of a totalizing meter in the pipeline (fig. 1) in successive increments of from 3- to 6 -inch depth, until the required amount was applied. A portable pipe and firehose were used to convey water from the hydrants at the head of each strip to the leaching plots. No attempt was made to keep the surface of the soil covered with water. The water applications were made merely in rotation from one plot to another at intervals of from one to three days until the required amount had been applied.

Cropping. After the initial leaching treatments of $0,1,2$, and 4 feet of water were applied in 1951, and again after leaching with the two additional 4 -foot increments in 1952, the cross-borders in each strip were leveled down; 16-20-0 fertilizer was broadcast at the rate of 60 pounds per acre ; and a crop of Kanota red oats was planted in each plot and throughout the entire length of the border strip. The oat crop was irrigated by flooding between borders. Frequent water applications of from 2 to 3 inches each were made on each strip to provide adequate moisture for the crop without deep leaching.

The first oat crop was harvested June 6, 1951, and the second on May 21, 1952. The average yield of both grain and straw was obtained from each plot by averaging the measured yield from four 1-yard square quadrats from within each plot.

Soil Sampling. Soil samples were taken from the plots before and after the initial leaching in 1950 and after each additional 4-foot increment of water was applied in 1951 (fig. 1). Samples were obtained with a 2-inch barrel-type auger by making four borings within each plot located midway between the center and each corner. The samples from the same depth intervals from these four locations were composited. Sampling depths were 0 to 6,6 to 12 , 12 to 24,24 to 42 , and 42 to 60 inches. A total of 240 soil samples was obtained in four samplings during the experimental period.

Soil and Plant Analyses. The change in salt content that occurred as a result of leaching was determined by electrical conductivity measurements of the saturation extract of the samples taken at the various intervals of leaching. The boron content of the saturation extract was also determined. In addition to the physical and chemical data reported in table 4, exchangeable sodium determinations were made on soil samples from the first two depths 0 to 6 and 6 to 12 inches from one plot of each of the treatments 1, 2, and 4 feet of water.

Determinations of the boron concentration in the oat straw were made for the oat samples obtained in 1951 and the concentration of boron in the oat grain for the harvest samples of both 1951 and 1952. All plant and soil determinations were made in accordance with the methods given in United States Department of Agriculture Handbook No. 60 (1954). 


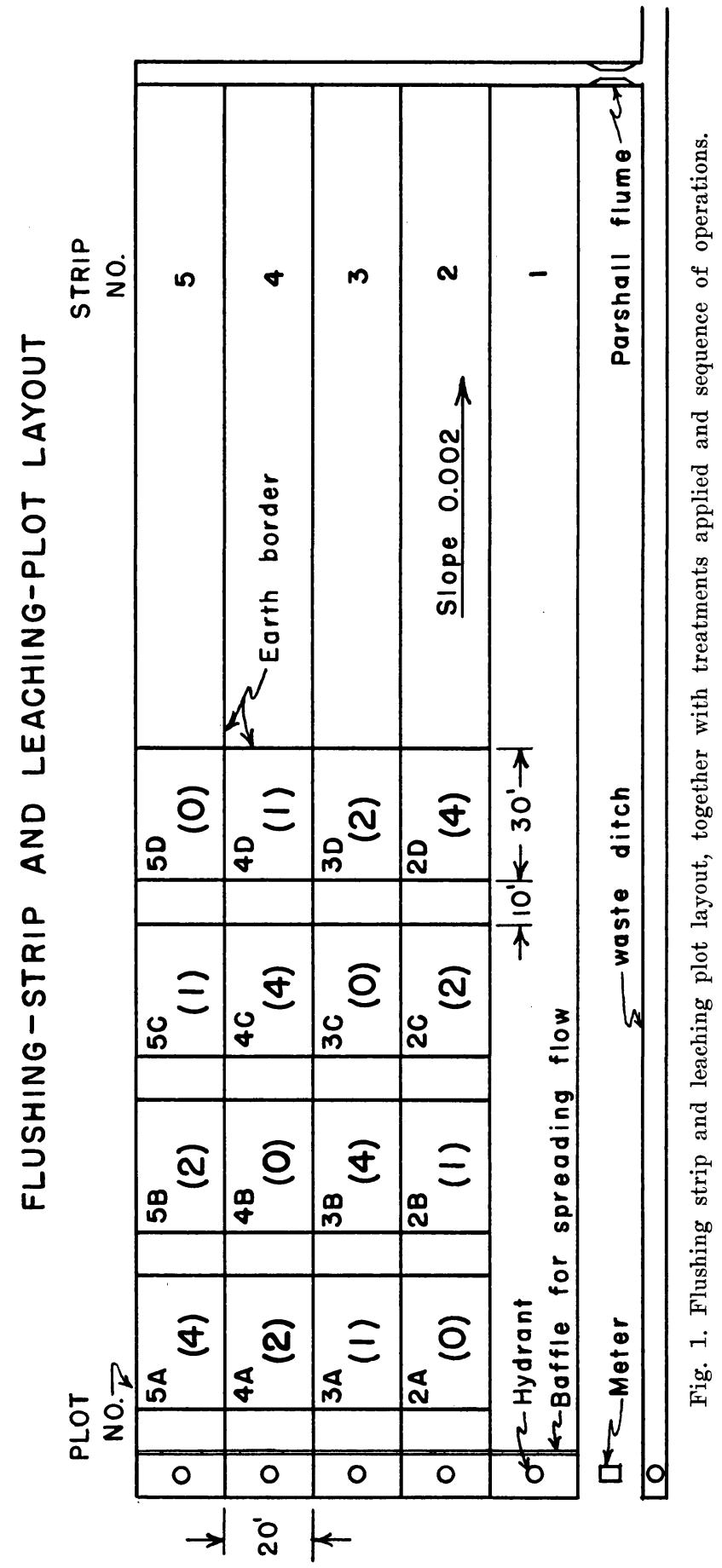




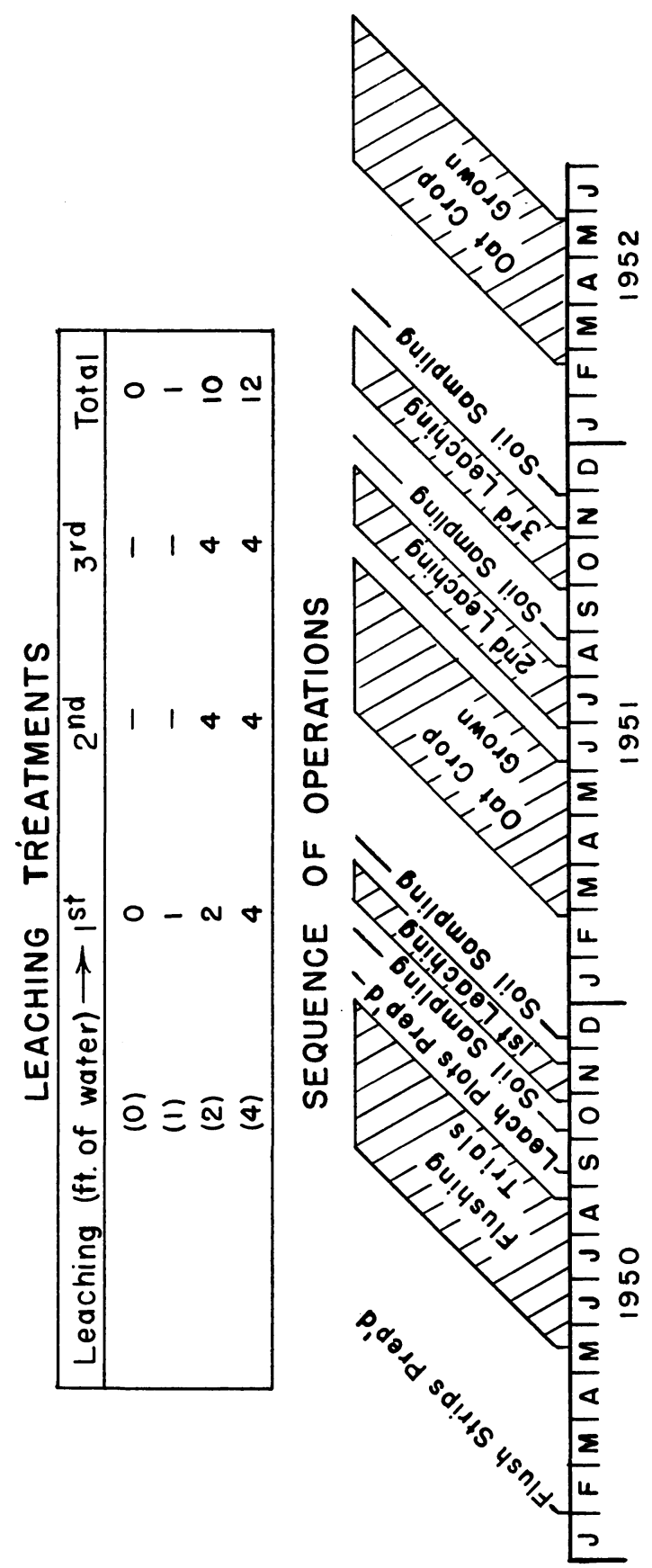




\section{RESULTS}

Effectiveness of Flushing. The electrical conductivity of the water discharged from the terminal end of the flushing strip increased to a maximum of about 16 times the electrical conductivity of the water admitted to the plots. However, the electrical conductivity dropped very rapidly and leveled

Table 6

AVERAGE REMOVAL OF SALT FROM THE SOIL SURFACE BY FLUSHING

\begin{tabular}{|c|c|c|c|c|c|c|}
\hline \multirow{2}{*}{$\begin{array}{l}\text { Flow rate, } \\
\text { cubic feet } \\
\text { per second }\end{array}$} & \multicolumn{3}{|c|}{ Depth of water } & \multirow{2}{*}{$\begin{array}{l}\text { Salt on, } \\
\text { tons per acre }\end{array}$} & \multirow{2}{*}{$\begin{array}{l}\text { Salt off, } \\
\text { tons per acre }\end{array}$} & \multirow{2}{*}{$\begin{array}{l}\text { Net salt } \\
\text { removal, } \\
\text { tons per acre }\end{array}$} \\
\hline & Applied & Runoff & Infiltrated & & & \\
\hline 2.6 & $\begin{array}{l}\text { inches } \\
5.2\end{array}$ & $\begin{array}{c}\text { inches } \\
2.3\end{array}$ & $\begin{array}{c}\text { inches } \\
2.9\end{array}$ & 0.35 & 1.29 & 0.94 \\
\hline
\end{tabular}

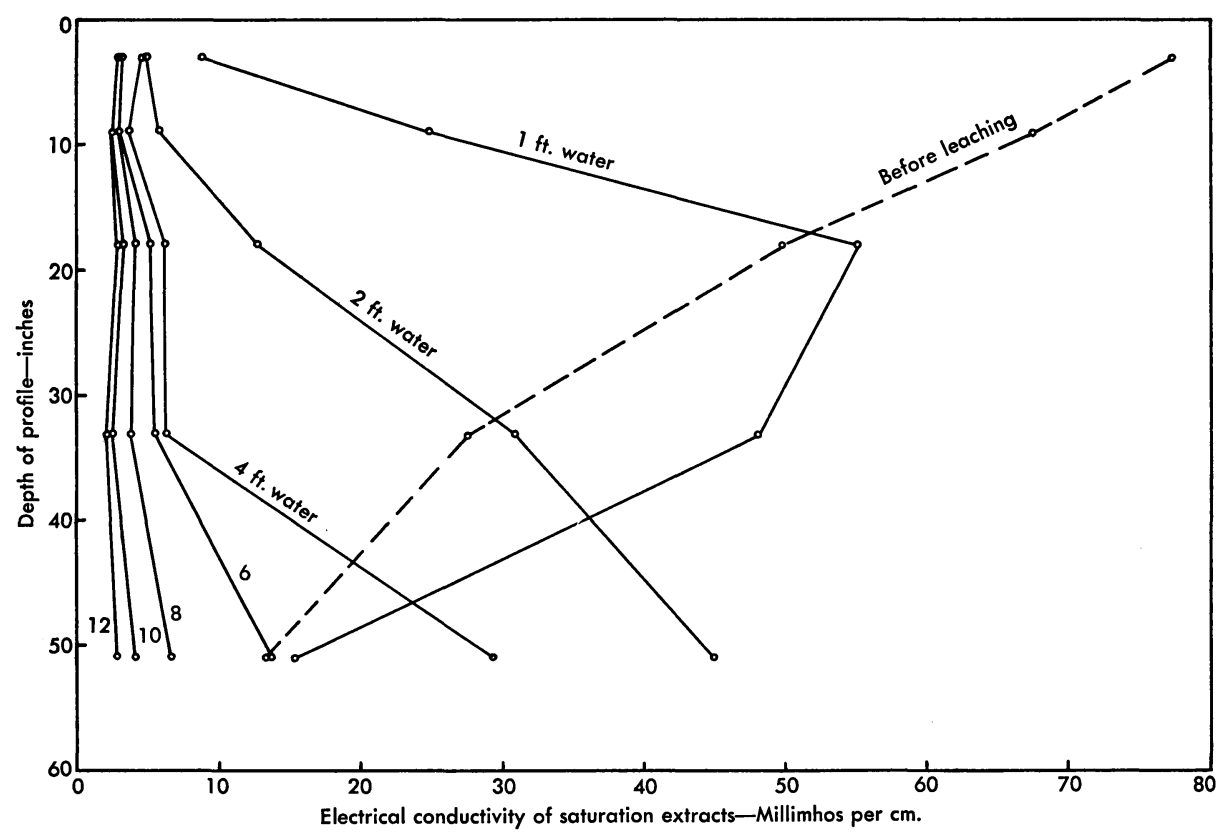

Fig. 2. Distribution of salt in soil profile before and after leaching, as measured by electrical conductivity of the saturation extract.

off to a value only slightly higher than that of the inflowing water in a period of about 20 minutes. The results of the flushing trials are summarized in table 6 . Considering the concentration and the quantity of water both on and off the plots, the net salt removal from a 320-foot strip was low as compared with the total salt content of the soil profile.

The values in the table are averages for five flushing strips, each having an area equal to 0.12 acre. The average net salt removal of 0.94 ton per acre is approximately 1 per cent of the total salt content of the first 2 feet of the soil profile. 
Effectiveness of Leaching. The distribution of salt in the soil profile both before and after leaching, as measured by the electrical conductivity of the saturation extract, is shown in figure 2. Before leaching, the salt was highest at the surface and decreased with depth. This distribution is typical of soils that have been salinized by movement of water upward from a water table, with evaporation at the soil surface. It is evident from the figure that leach-

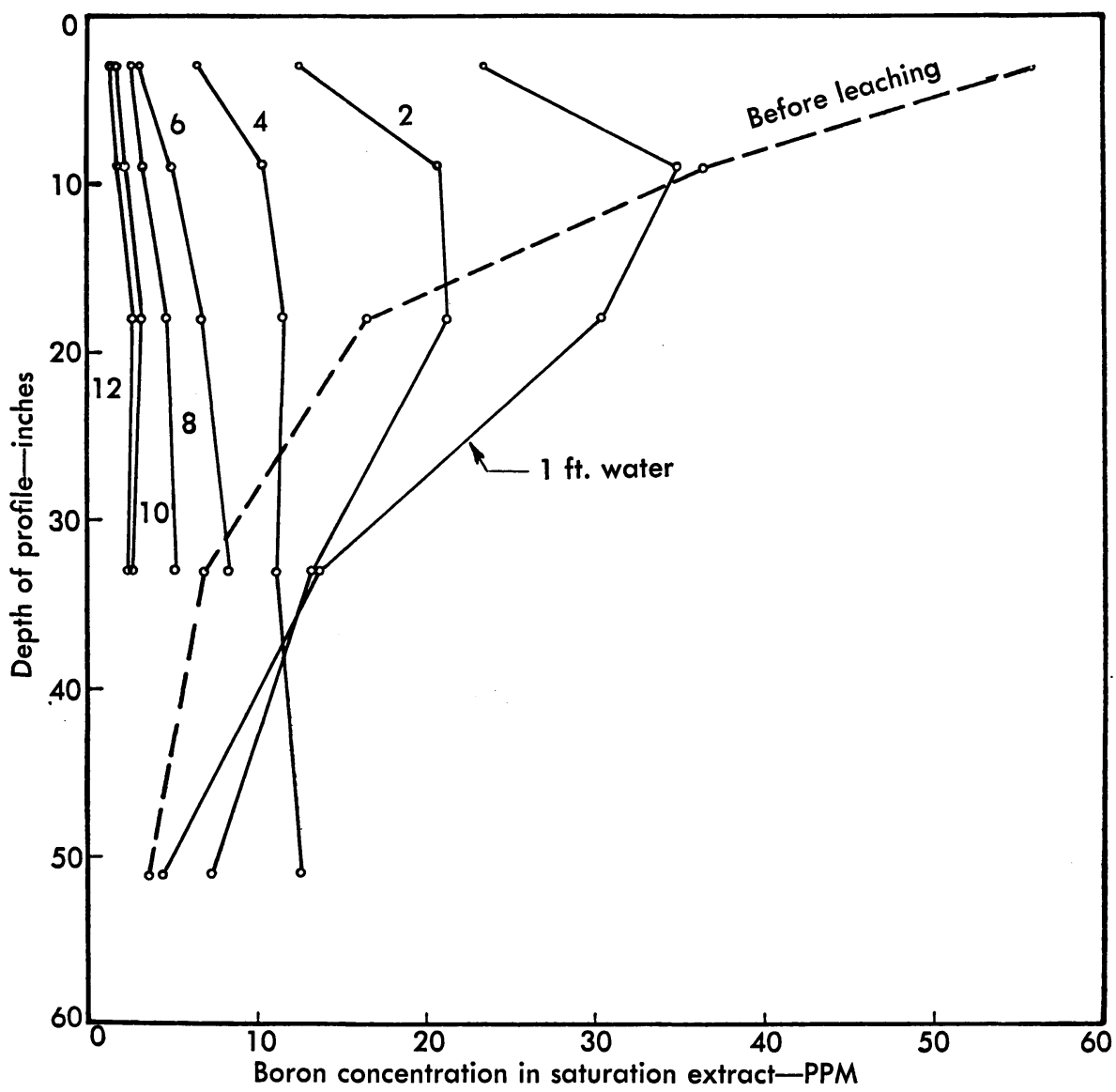

Fig. 3. Distribution of boron in soil before and after leaching as measured in saturation extract.

ing with increasing amounts of water displaced the salt to an increasing depth below the soil surface. After leaching with 4 feet of water, the salt content is reduced to a value less than 5 millimhos per em at the surface and is essentially constant to a depth of 42 inches.

The distribution of boron in the soil profile, as measured in the saturation extract before and after leaching, is shown in figure 3. The initial boron distribution in the soil profile is similar to that for total salt. With increasing leaching applications the boron was displaced to greater and greater depths 


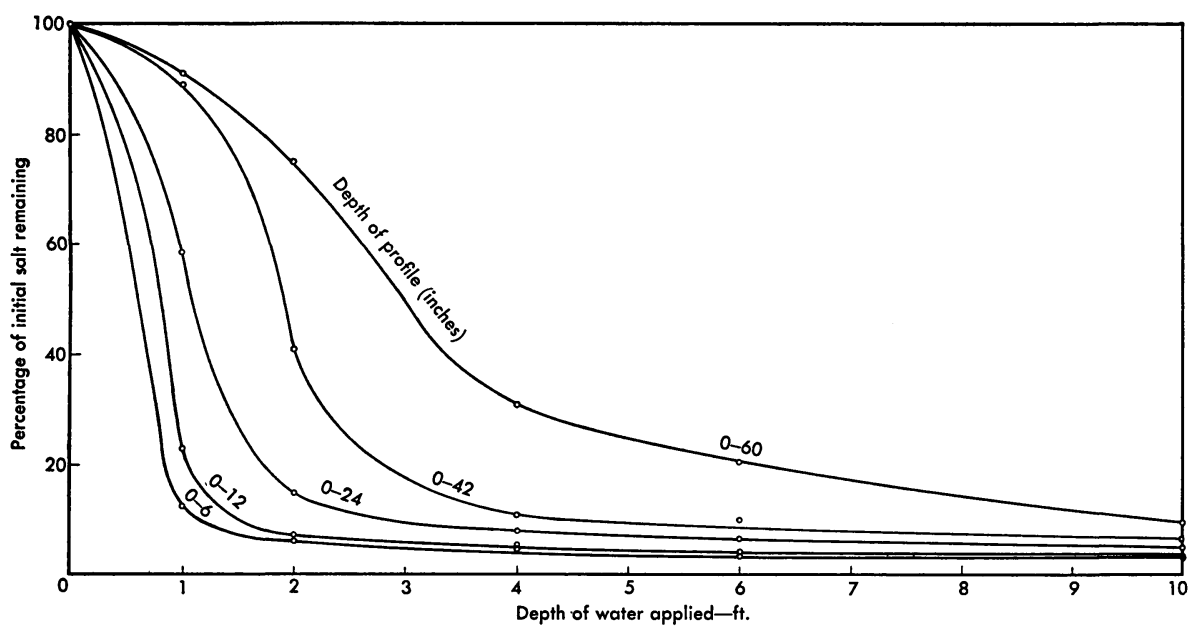

Fig. 4. Percentage of initial salt remaining in soil for various profile depths as related to depth of leaching water applied.

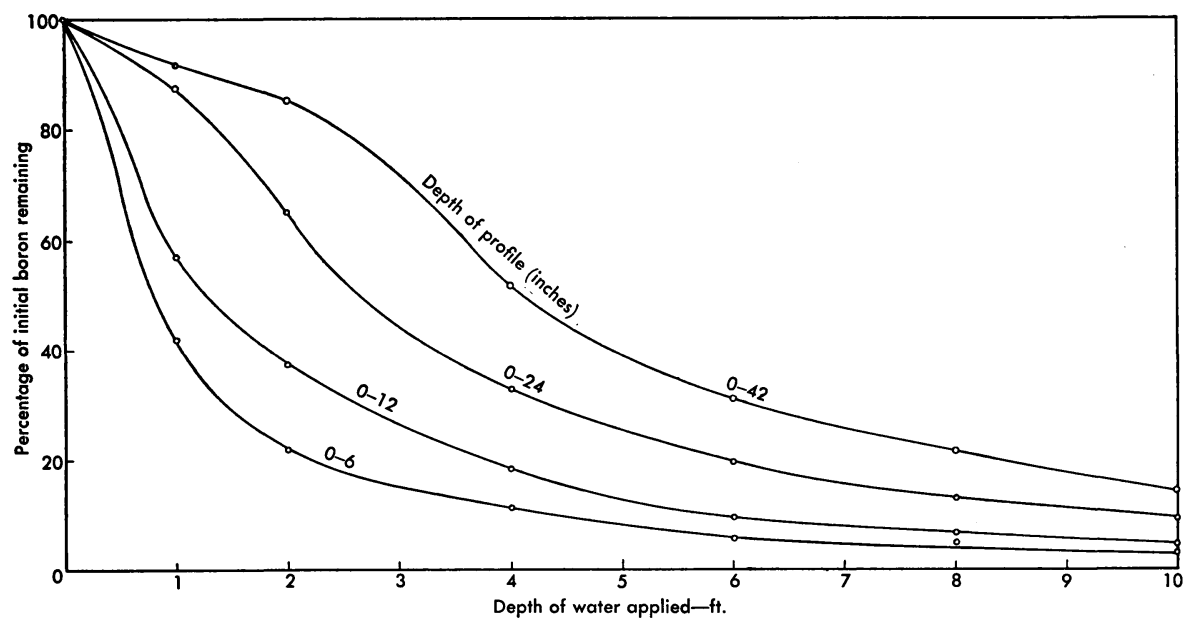

Fig. 5. Percentage of initial boron remaining in soil for various profile depths as related to depth of leaching water applied.

within the soil profile. Although the distribution of boron was similar to that of total salt, there was a marked difference in the effectiveness of the leaching water in removing these constituents from the soil. The extent of leaching expressed in terms of the percentage remaining, as related to depth of water applied for five profile depths, is shown for salt in figure 4 and for boron in figure 5 .

The slope of the curve at any given depth of water applied is a measure of the effectiveness with which the leaching water removed salt or boron for a given profile depth at that particular stage of leaching. It is evident by comparing the two figures that salt was removed more efficiently than boron. The 
rate of removal, all profile depths considered, was much greater for salt than for boron.

Inasmuch as the processes involved in leaching are independent of the geometry of the system, the curves representing the data for several profiles may be combined into a single curve by expressing the leaching in terms of the depth of water applied per unit depth of soil. Figure 6 shows the data for

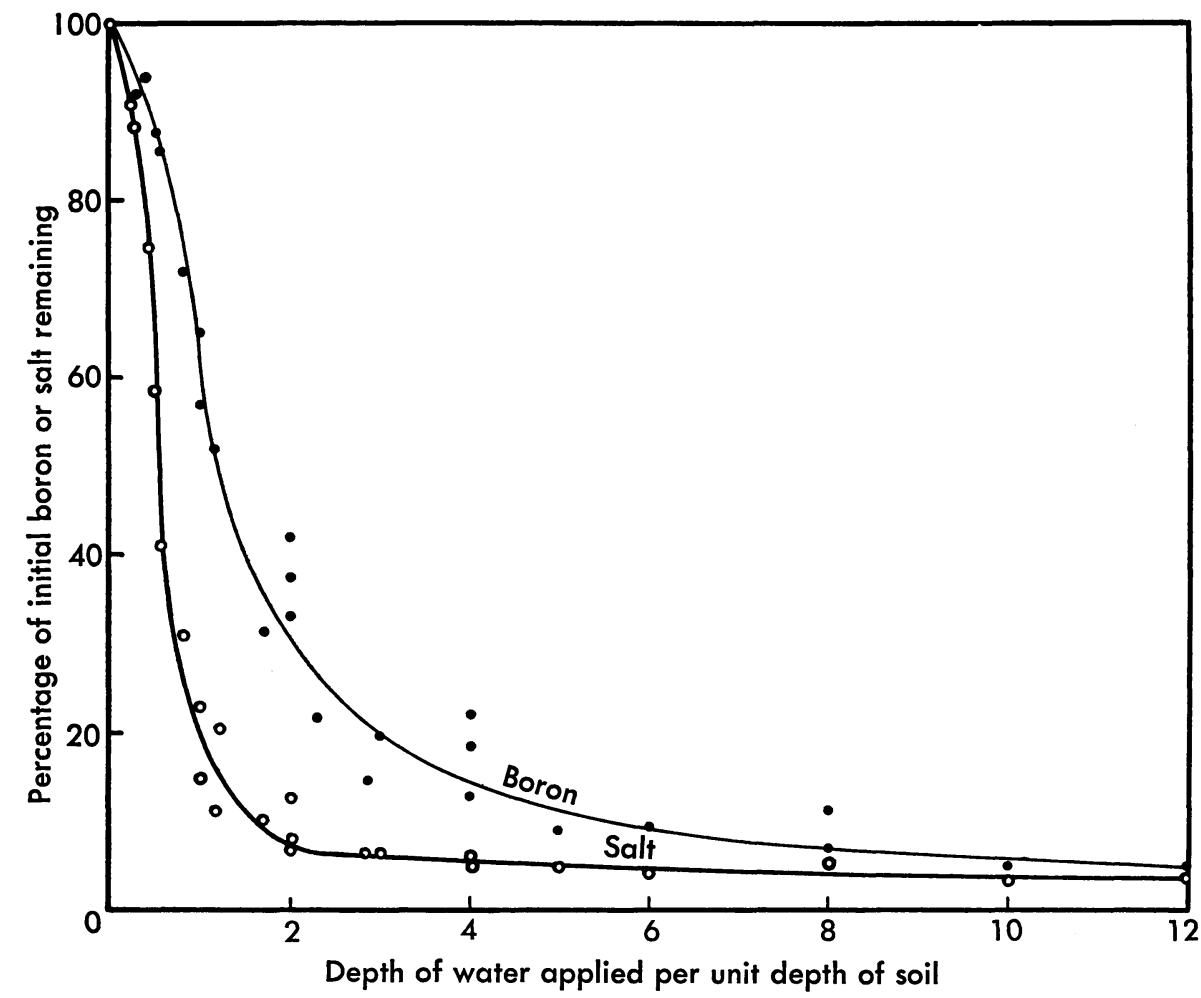

Fig. 6. Percentage of initial boron and salt remaining in soil profile as related to depth of leaching water applied per unit depth of soil.

five profiles combined into a single curve for the leaching of both boron and salt. Here again the greater efficiency of the leaching water in removing salt as compared with boron is indicated.

Chemical Changes as a Result of Leaching. Table 7 shows the cation exchange capacity and the exchangeable sodium status of the soil at depths of 0 to 6 and 6 to 12 inches before and after leaching with 1, 2, and 4 feet of water. Although the exchangeable sodium percentage was excessively high before leaching, there was a marked reduction in the exchangeable sodium merely by leaching with water. There was sufficient gypsum present in the soil to replace virtually all of the exchangeable sodium. As indicated in table 4 , the gypsum content of the soil before leaching was 58 and $36 \mathrm{meq} / 100 \mathrm{gm}$ for the 0 - to 6 - and 6 - to 12 -inch depths, respectively.

Crop Response. The average yields of oat grain and oat straw for the plots leached with different amounts of water for both 1951 and 1952 are shown 
in table 8 . The yield of oat grain as related to the depth of water used for leaching is shown in figure 7 . Although yield data were not obtained for intermediate leaching levels between 4 and 10 feet of water, a smooth curve fitted to the points shows that essentially maximum yield would have been obtained after leaching with 6 to 7 feet of water.

Table 7

EXCHANGEABLE SODIUM STATUS OF THE SOIL BEFORE AND AFTER LEACHING

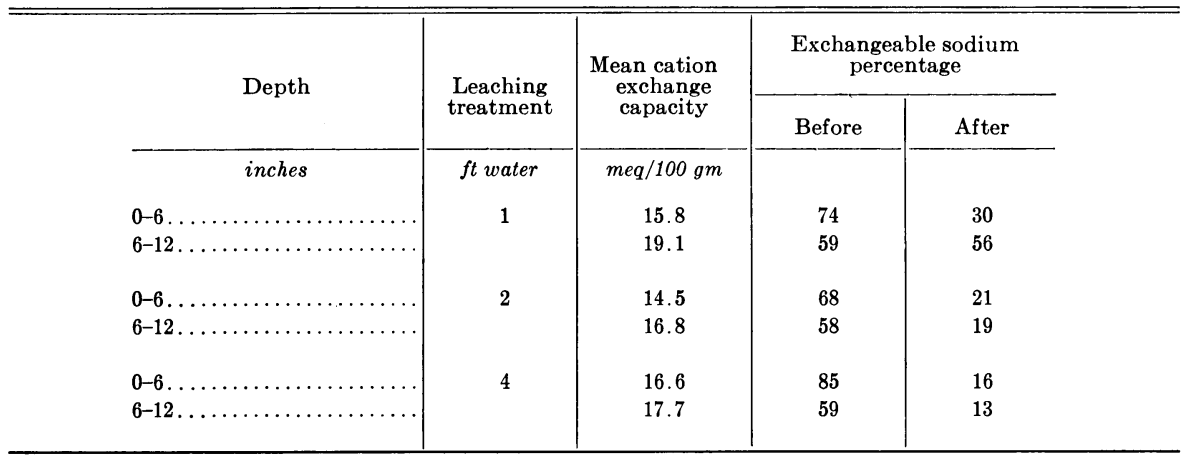

Table 8

AVERAGE YIELDS OF OAT GRAIN AND STRAW FROM PLOTS LEACHED WITH DIFFERENT AMOUNTS OF WATER

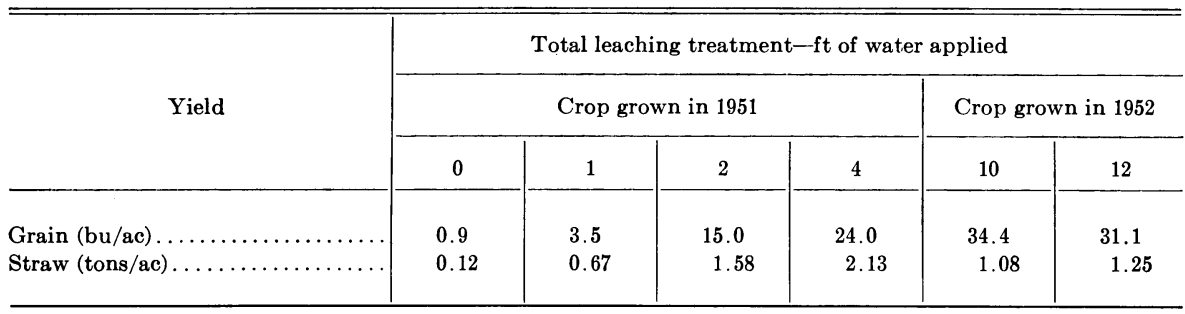

During the growing period of the oat crop in 1951, serious crop injury was indicated by tip and marginal burning of the leaves. Determinations of the boron concentration in the plant material, oat grain and oat straw, and in the saturation extract of the soil showed that boron was the major factor in limiting crop growth. Although salt was present in excessive amounts at the beginning of the experiment, the difference in the rate of removal of salt and boron was such that boron was the principal factor limiting crop growth. Multiple linear correlation analyses gave the equation $\mathrm{Y}=33.70-1.22 \mathrm{~B}+$ $0.28\left(\mathrm{EC}_{\mathrm{e}}\right)$ in which $\mathrm{B}=$ boron concentration in ppm in the saturation extract and $\mathrm{EC}_{\mathbf{e}}=$ electrical conductivity of the saturation extract. It was further shown that 78 per cent of the variance in grain yield was associated with the boron concentration in the saturation extract of the soil. The regres- 


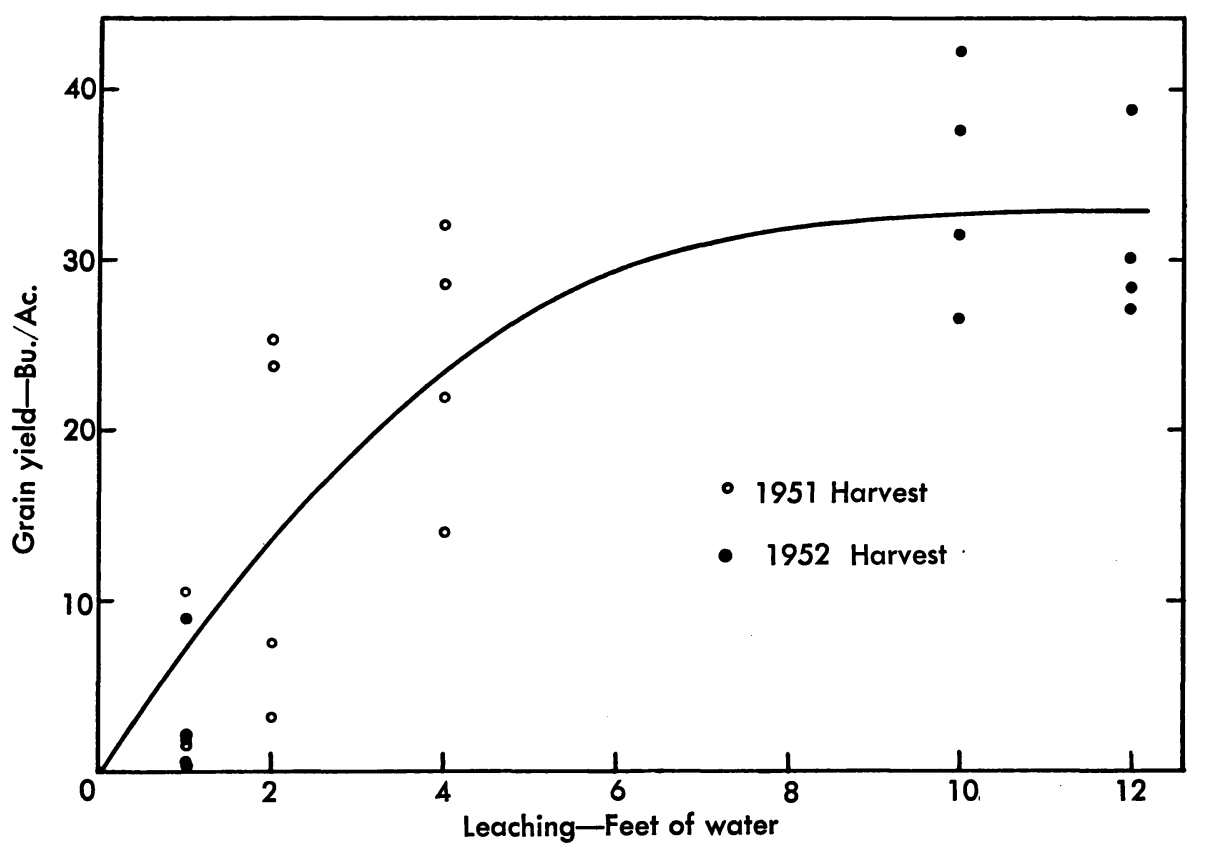

Fig. 7. Oat grain yield as related to depth of leaching water applied.

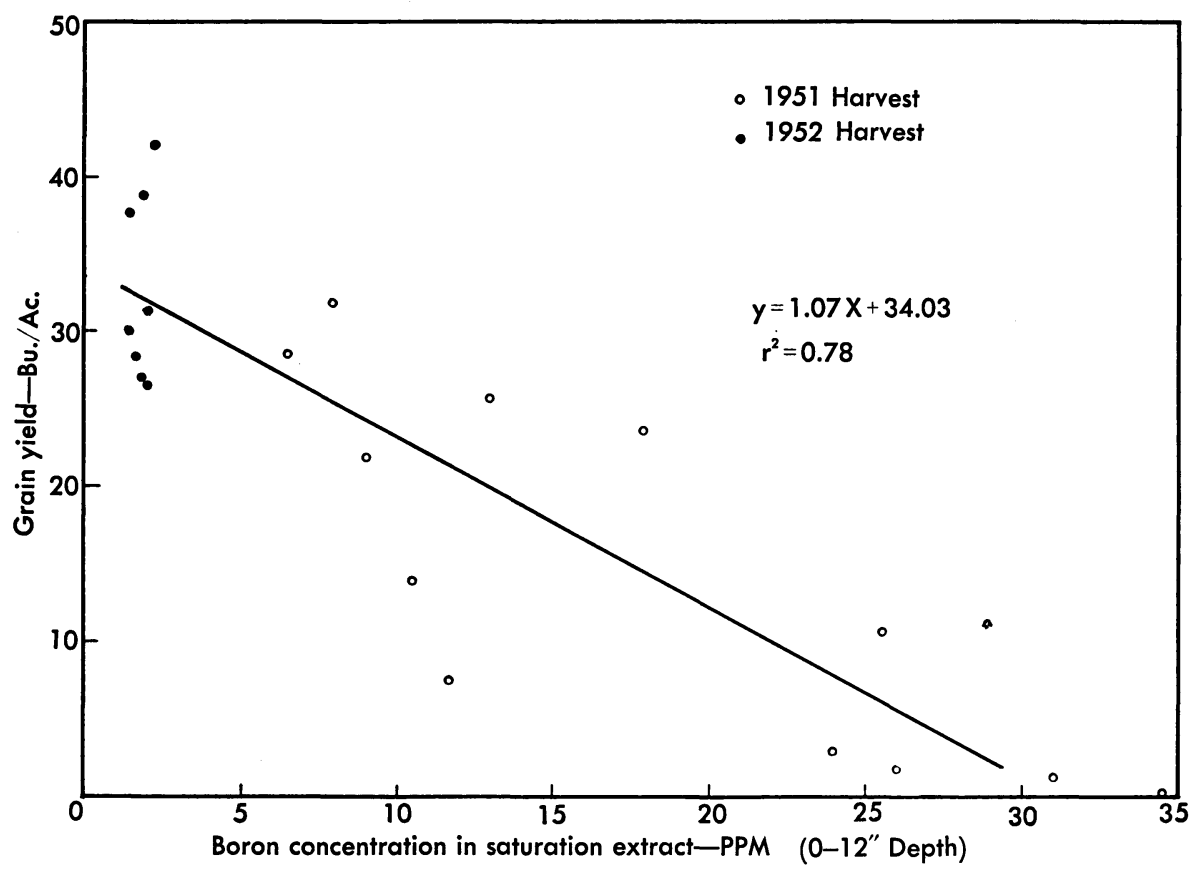

Fig. 8. Yield of oat grain as related to boron concentration of saturation extract of 0 - to 12-inch depth interval. 
sion coefficient for boron was significant at the 1 per cent level, whereas the regression coefficient for salt was not significant even at the 5 per cent level. Figure 8 shows the grain yield simply related to the boron concentration of the saturation extract of the 0 - to 12-inch depth or root zone of the soil.

Figure 9 shows the oat yields as related to the boron concentration of the oat grain and the oat straw. In both instances the yield of oats is inversely related to boron uptake. Assuming that the linear relationship applies, a concentration of $200 \mathrm{ppm}$ in the grain and $1,500 \mathrm{ppm}$ in the straw corresponded to approximately a 50 per cent decrease in grain and straw yields, respectively.

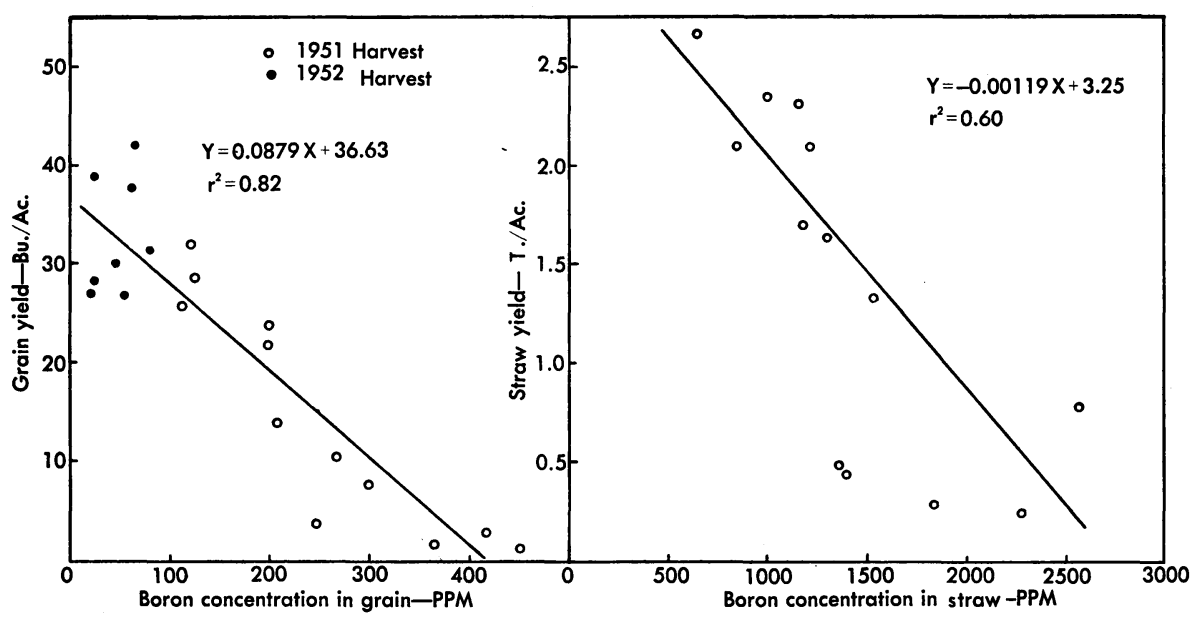

Fig. 9. Oat yields as related to boron concentration in oat grain and in oat straw.

\section{DISCUSSION}

Flushing. This was proposed as a preliminary method of salt removal (Huberty, et al., 1948) that might in some instances simplify subsequent leaching. Where there were high concentrations of salt, predominantly at the surface, and where permeability was so low that leaching was difficult, flushing could conceivably remove some of the surface salts, thus decreasing the amount that must be moved down through the profile. Recognized were further limitations, including the need to apply large flows to large tracts of land of favorable topography. The exploratory experiment described by Huberty, et al., indicated that some salts could be flushed off for a short period of time, but it did not provide sufficient quantitative information to determine the relative importance of flushing.

The data herein reported (table 6 ) were obtained under favorable conditions in the occurrence of a salt crust, in microrelief of the soil surface, and in the flow available. Under these circumstances about 1 ton of salt per acre per flushing was removed. This was about 1 per cent of the salt in the surface 2 feet. By comparison, leaching with 2 feet of water per foot depth of soil removed more than 90 per cent of the salt. Failure of flushing to be significantly effective can be attributed to the fact that intake of water into the 
dry soil initially high. At the points of contact between water, salt crust, and soil, at which points the salts are taken into solution, there are two flow components. One of these is lateral, on the surface, and the other is downward. The downward component moves salt into rather than off of the soil. The soil at this site can be classed as moderately permeable. Under these conditions, flushing is obviously not economically feasible. At least in Coachella Valley it has two other practical limitations: 1) a microrelief too variable to accommodate the uniform spreading out of the water on idle or virgin lands where salt crusts occur; and 2) in general, means of disposing of flushing waters are lacking.

Leaching. The more important processes involved in leaching salts from soils are: 1) displacement downward in the soil of the salts that are in solution in the soil water; 2 ) solution by the percolating water of salts that are in the soil in crystalline form; and 3) the exchange of cations that occur between the cation exchange complex of the soil and the leaching water. In considering these processes it is expected thatrthe first increment of water to pass through a highly saline soil would be the most effective in removing salts, and that with the passage of successive increments the effectiveness of the leaching water in removing salts would decrease. This has been demonstrated in these experiments, as reported in figure 6. Similar results were also obtained in previous studies in the Delta Area of Utah by Reeve, et al., in 1948. Although the rate of salt removal decreased as leaching progressed, the yield of wheat in the Utah studies increased more and more rapidly as the electrical conductivity of the saturation extract of the root zone soil decreased The experimental results showed that the various factors involved were so related that, from virtually zero yield at no leaching to maximum vield obtained with 4 feet of water, the yields of wheat inereased approximately linearly with increasing depth of water applied.

These relationships for the present study cannot be similarly compared because erop growth was limited by boron in the soil instead of total salt. However, for both the Utah and the Coachella studies, which involved gypsiferous saline-alkali soils, the quantity of water required for leaching, as measured by a change in the salt contained in the soil, was essentially the same in both cases. To reduce the salt content of the soil to about 20 per cent of the initially high value, 1 foot of water was required for each foot of soil considered.

It is of interest that the closeness of fit of the data points around a central curve for both salt and boron (fig. 6). This is reasonably good in view of the nonhomogeneity and differences in moisture and salt distribution within the several soil profiles considered. The data from the profiles reported in figures 4 and 5 are used to construct the curves of figure 6. Expressing the leaching in terms of unit depth of water applied per unit depth of soil is justified upon the basis that for the idealized case, leaching is independent of the geometry of the system. Where soil properties and moisture and salt distribution are invariable, the quantity of salt removed, expressed as a fraction or percentage of the initial salt content of the profile, will be the same for all profile depths if the depth of water applied is proportional to the depth of profile. That is to say, leaching will be as effective where 1 foot of water is 


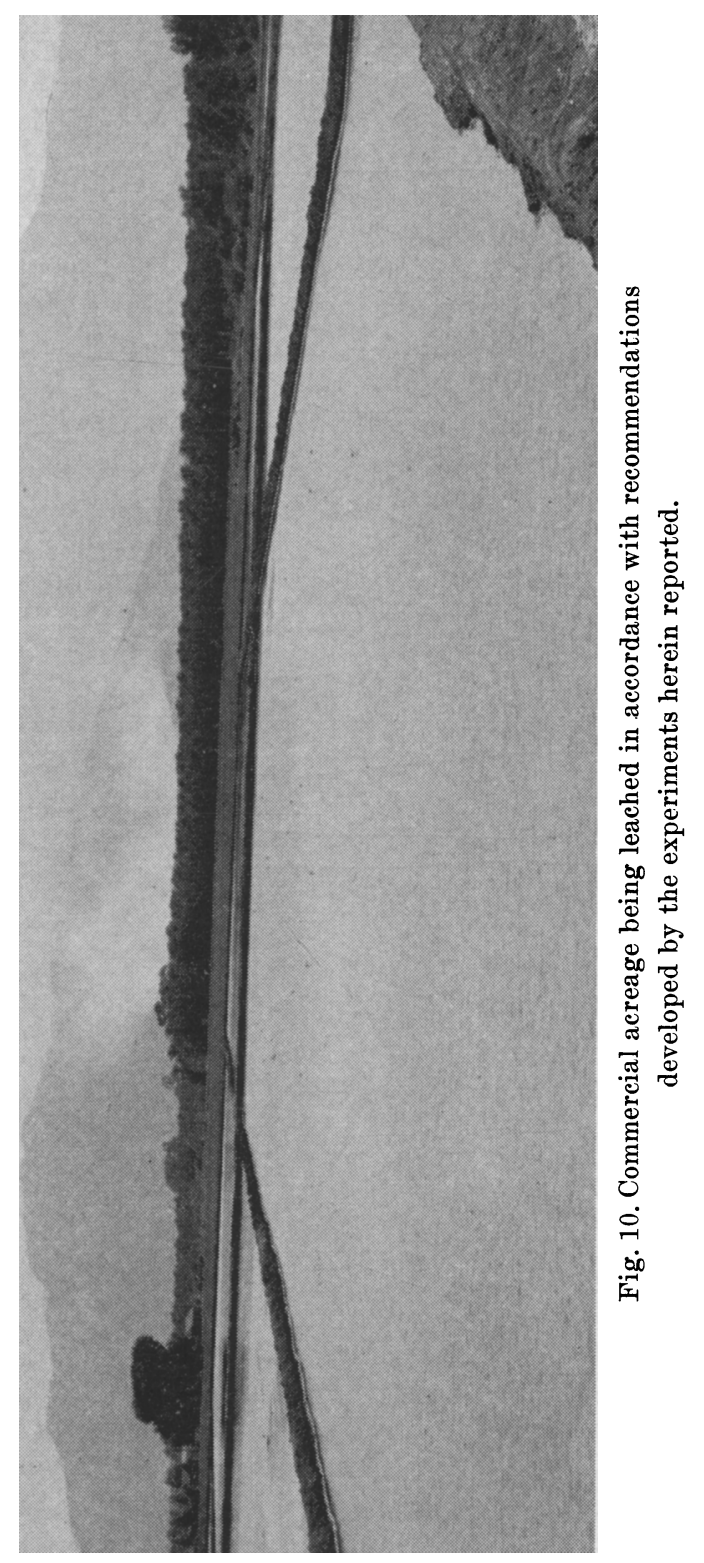




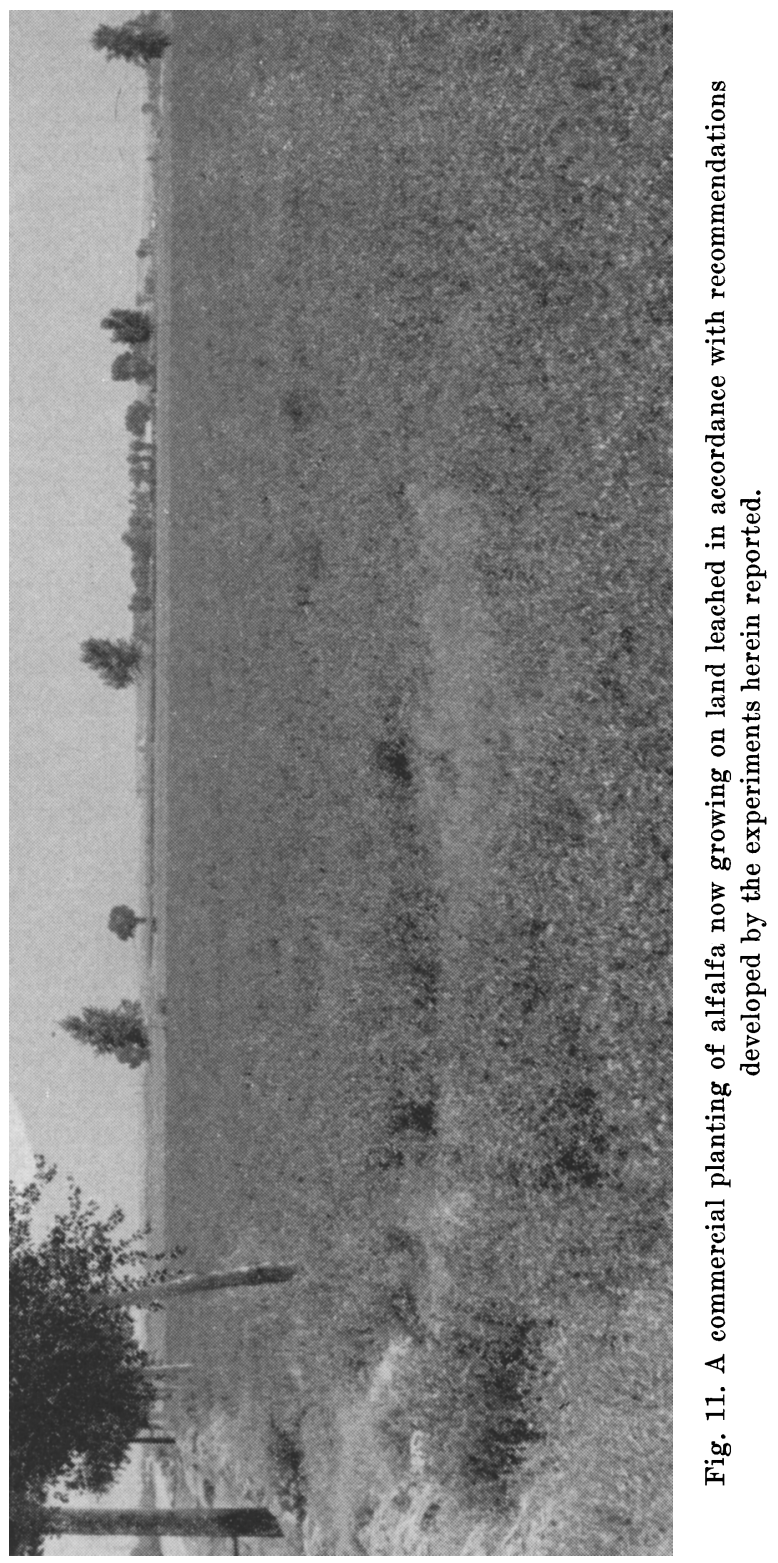


passed through 1 foot of soil as it will where 2 feet of water are used to leach 2 feet of soil. Inasmuch as the actual conditions of homogeneity of the soil and differences in salt and moisture distribution varied considerably, the relatively small scatter of data points about the respective curves indicates that the leaching processes of displacement and solution are not appreciably affected by soil nonhomogeneity and initial salt and moisture distribution. The quality of the water used for leaching influences the reclamation, but may or may not have an appreciable effect upon the final result. The total concentration of salt in the leaching water determines the ultimate level of salinity to which the soil can be leached, and if leaching progresses until this limit is reached, the resulting cation exchange composition of the soil will be determined by the composition of the water.

In these studies the average electrical conductivity of the saturation extract of the 0 - to 6 -inch profile, after leaching with 12 feet of water, was 3.7 millimhos per centimeter. This value is somewhat higher than would be expected from the electrical conductivity of the leaching water $\left(\mathrm{EC} \times 10^{3}=\right.$ 1.1). In this instance, gypsum was present in the soil in large amounts, and because of its limited solubility, apparently had an important effect upon the final salinity level of the soil.

Boron. As indicated by the data of figure 6 , there is a wide difference in the efficiency with which water removes salts from the soil as compared with boron. This is in agreement with observations of earlier investigators (Kelley and Brown, 1928; Scofield and Wilcox, 1931; Eaton, 1935; Eaton and Wilcox, 1939 ; Eaton, et al., 1941) ; however, the processes involved in bringing about this slower rate of removal are not well understood. Boron is known to be adsorbed by soils and it may be that the apparent slow rate of dissolution is related to this phenomenon but it is not believed to be a solubility effect.

The damage to the oat crop evidenced by tip and marginal burning of the leaves resulted from an accumulation of boron in the plant tissues. Boron was found to accumulate in all of the aboveground portion of the plant but was most highly concentrated in the leaves. The roots were not examined. Oat plants having a concentration of boron in the grain of less than $20 \mathrm{ppm}$ and in the oat straw of less than about 500 appeared to have made normal growth.

\section{SUMMARY AND CONCLUSIONS}

During the period February, 1950, to May, 1952, a field plot experiment was conducted on a virgin saline-alkali soil in the Coachella Valley, California. The soil studied contained excessive amounts of soluble salts and exchangeable sodium. Boron was also present in amounts toxic to an oat crop. Gypsum occurred in the soil in sufficient amounts to replace the exchangeable sodium. The soil was classified as Indio clay loam, silty phase, and although high in silt, the permeability of the soil was sufficiently high to permit leaching. Drainage conditions were adequate.

The purpose of the experiment was to determine the effectiveness of flushing, a method designed to move salts laterally from the soil surface, as compared with leaching, and to determine the quantity of water that was re- 
quired to effectively leach both excess salt and boron downward through the soil.

Flushing was evaluated by measuring the net quantity of salt discharged with the water from the end of flushing strips, and the effectiveness of leaching was determined both by soil analyses and by crop response. Inasmuch as boron was found to be difficult to leach from the soil, three separate leaching applications were made during the two-year period. The initial leaching treatments consisted of 0-, 1-, 2-, and 4-foot depth of water replicated four times in a Latin square arrangement. The second leaching consisted of a 4 -foot depth of water applied to plots already leached with 2 and 4 feet of water and the third leaching consisted of an additional 4-foot application on the same group of plots. Thus the leaching treatments included 6, 8, 10, and 12 feet of water in addition to those listed above. Soil samples were taken after each leaching to determine the salinity status of the soil. An oat crop was grown on the flushing and leaching plots in the spring of 1951 following the initial leaching and again in the spring of 1952 following the third leaching.

The following conclusions are drawn from this study:

1) Both excessive salts and boron can be effectively leached from the soil. The rate of removal was greater for salt than for boron. The salt content of the soil at the experimental site under study was reduced to less than 20 per cent of the initially high value with 1 foot of water for each 1-foot depth of soil considered, whereas 3 feet of water for each 1-foot depth of soil was required for the same percentage reduction in boron.

2) The quantity of gypsum present in the soil at the experimental site was sufficiently high to replace the initially high exchangeable sodium. Leaching with water was all that was required to reclaim this soil.

3 ) Flushing water over the soil surface resulted in the removal of only 1 ton of salt per acre per flushing. This is about 1 per cent of the salt removed from the first 2 feet of soil by leaching. Flushing is most effective when salt is crusted on the soil surface, when physical conditions are such that a rapidly moving surface sheet of water will spread out uniformly without much erosion, and when the infiltration rate is low. In the present case the infiltration rate was only moderately low (average less than 0.3 inch per hour for 4-foot depth of application), but the other conditions were unusually favorable for flushing. From this test, therefore, it is concluded that surface flushing will not often be a justifiable procedure in the reclamation of saline soil.

4) Because of the differential leaching rates of boron as compared with salt, the yield of an oat crop grown on the soil following leaching was found to be dependent upon the boron level in the soil. Yields were noticeably reduced on plots where the concentration of boron was as low as $5 \mathrm{ppm}$ in the saturation extract. At a concentration of $15 \mathrm{ppm}$ of boron in the saturation extract, oat yields were reduced approximately 50 per cent. Although the variations in the field yield data reported do not permit the evaluation of differences in yield for small increments of boron, it is likely that boron concentrations as low as 2 to $3 \mathrm{ppm}$ in the saturation extract would have a detrimental effect on oat yields. 


\section{ACKNOWLEDGMENTS}

The studies reported herein are part of a coöperative research project, initiated in 1945 and still continuing, that deals with drainage and reclamation in Coachella Valley. The research is directed by a committee made up of representatives of each agency. Present and previous committee members, the latter shown in parenthesis, follow:

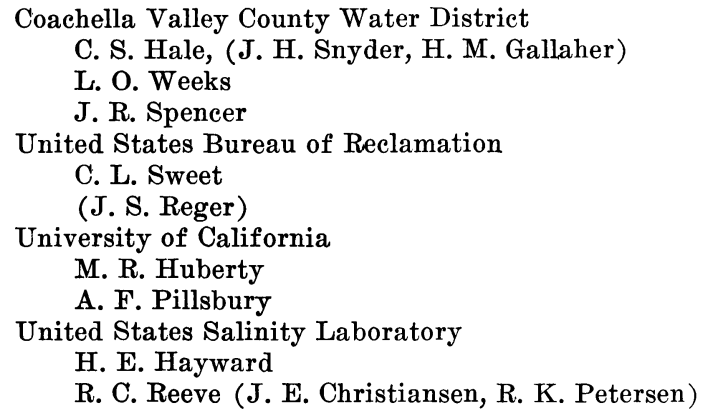

The direction and assistance of the committee have been most helpful in the conduct of the work and in the preparation of this report. Further, without the interest and active budgetary support provided by the Board of Directors of the Coachella Valley County Water District, the work could not have been accomplished. L. O. Weeks, J. R. Spencer, and Ray Hamilton of that organization took an especially prominent part in the planning and execution of the work. N. L. McFarlane and Dean F. Halsey of the University of California Agricultural Extension Service, Riverside County, provided both counsel and assistance.

Staff members and technicians of the Coachella Valley County Water District, the University of California Department of Irrigation and Soils, and the United States Salinity Laboratory advised and assisted the authors. Those whose contributions were particularly valuable and who are not members of the Coöperators' Committee follow: Ray Hamilton, Coachella Valley County Water District; R. H. Brooks, J. T. Hatcher, and R. W. Austin, United States Salinity Laboratory. 


\section{LITERATURE CITED}

Bower, C. A., L. R. Swarner, A. W. Marsh, and F. M. Tileston

1951. The improvement of an alkali soil by treatment with manure and chemical amendments. Oregon Agr. Exp. Sta. Tech. Bul. 22.

BURGESS, P. S.

1928. Alkali soil studies and methods of reclamation. Arizona Agr. Exp. Sta. Bul. 123.

CATtin, C. N., and A. E. Vinson

1925. Treatment of black alkali with gypsum. Arizona Agr. Exp. Sta. Bul. 102.

EATON, Frank M.

1935. Boron in soils and irrigation waters and its effect on plants, with particular reference to the San Joaquin Valley of California. U.S. Dept. Agr. Tech. Bul. 448.

Eaton, F. M., R. D. McCallum, and M. S. Mayhugh

1941. Quality of irrigation waters of Hollister Area of California, with special reference to boron content and its effect on apricots and prunes. U.S. Dept. Agr. Tech. Bul. 746.

EATON, F. M., and L. V. WILCox

1939. The behavior of boron in soils. U.S. Dept. Agr. Tech. Bul. 696.

FitTs, J. W., E. S. Lyons, and H. F. RHOAdES

1943. Chemical treatment of "slick spots." Soil Sci. Soc. Amer. Proc. 8:432-36.

GARDNER, R.

1945. Some soil properties related to the sodium salt problem in irrigated soils. U.S. Dept. Agr. Tech. Bul. 902.

HARRIS, F. S.

1920. Soil alkali, its origin, nature and treatment. John Wiley and Sons, New York.

HILGARD, E. W.

1907. Soils. The Macmillan Co. New York.

Huberty, M. R., A. F. Pillsbury, and V. P. Sokolofr

1948. Hydrologic studies in the Coachella Valley, California. California Agr. Exp. Sta. (Lithoprint.)

KeLLEY, W. P.

1951. Alkali soils; their formation, properties and reclamation. 176 pp., illus. Reinhold Pub. Corp., New York.

Kelley, W. P., and S. M. Brown

1928. Boron in soils and irrigation waters of Southern California and its relation to citrus and walnut culture. Hilgardia 3 (16) :445-58.

KeLLeY, W. P., and E. E. Thomas

1928. The reclamation of the Fresno type of black-alkali soils. California Agr. Exp. Sta. Bul. 455:1-38.

KOCHER, A. E., and W. G. HARPER

1928. Soil survey of the Coachella Valley, California. U.S. Dept. Agr. Bul. 16, series 1923.

Reeve, R. C., L. E. Aluison, and D. F. Peterson, Jr.

1948. Reclamation of saline-alkali soils by leaching. Delta Area Utah. Utah Agr. Exp. Sta. Bul. 335.

Scofield, C. S., and L. V. WiLcox

1931. Boron in irrigation waters. U.S. Dept. Agr. Tech. Bul. 264.

SNYDER, R. S., M. R. KULP, G. O. BAKeR, and J. C. MARR

1940. Alkali reclamation investigations. Idaho Agr. Exp. Sta. Bul. 233.

Thomas, E. E.

1936. Reclamation of white-alkali soils in the Imperial Valley. California Agr. Exp. Sta. Bul. 601:1-16.

United States Department Agriculture

1954. Diagnosis and improvement of saline and alkali soils. U.S. Dept. Agr. Handbook 60. U.S. Govt. Print. Off., Washington, D.C.

Wursten, J. L., and W. L. Powers

1934. Reclamation of virgin black-alkali soils. American Soc. Agron. Jour. 26:752-62. 

The journal Hilgardia is published at irregular intervals, in volumes of about 600 pages. The number of issues per volume varies. Subscriptions are not sold. The periodical is sent as published only to libraries, or to institutions in foreign countries having publications to offer in exchange.

You may obtain a single copy of any issue free, as long as the supply lasts; please request by volume and issue number from:

Agricultural Publications

Room 22, Giannini Hall

University of California

Berkeley 4, California

The limit to nonresidents of California is 10 separate issues on a single order. A list of the issues still available will be sent on request. 


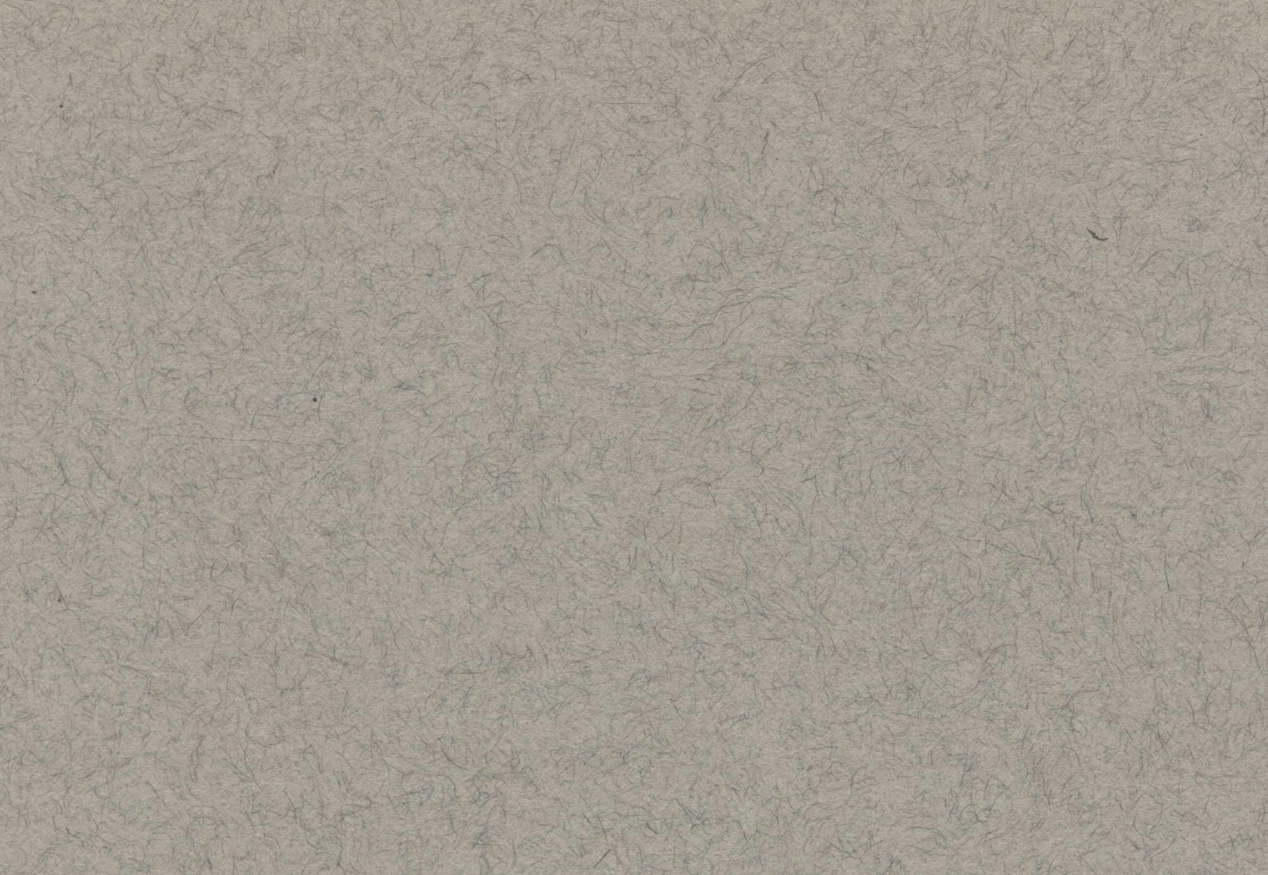

(1)

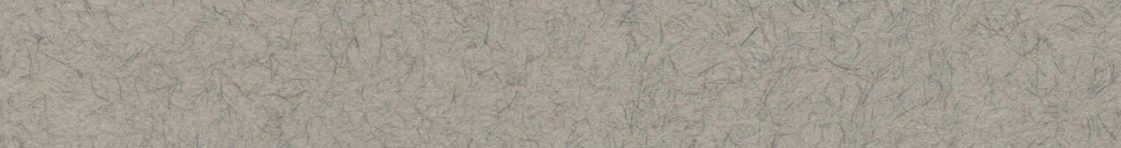

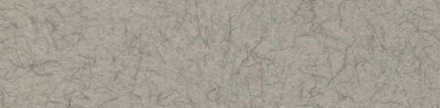

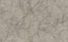

